\title{
APLIKASI SENSORIAL ARCHITECTURE PADA FASILITAS PENGOLAHAN DAN PENGELOLAAN SAMPAH PLASTIK DI KELURAHAN PAPANGGO
}

\author{
Jasmine Calista1) ${ }^{1)}$ Petrus Rudi Kasimun ${ }^{2)}$ \\ 1)Program Studi S1 Arsitektur, Fakultas Teknik, Universitas Tarumanagara, jcalista23@gmail.com \\ 2) Program Studi S1 Arsitektur, Fakultas Teknik, Universitas Tarumanagara, rudi.kasimun@gmail.com
}

Masuk: 04-07-2021, revisi: 15-08-2021, diterima untuk diterbitkan: 23-10-2021

\begin{abstract}
Abstrak
Plastik merupakan salah satu bahan yang paling sering digunakan karena sifatnya yang fleksibel, murah, dan tahan lama. Namun, meski mempunyai sifat yang tahan lama, banyak plastik yang hanya dipakai sekali sebelum akhirnya berakhir di TPA atau di lingkungan. Sifatnya yang tidak bisa / sulit terdegradasi menyebabkan dampak buruk pada lingkungan, terutama ekosistem laut. Perancangan fasilitas pengolahan dan pengelolaan sampah plastik merespon terhadap masalah ini dengan dua cara, yaitu melalui pengolahan sampah plastik menjadi bahan dasar filamen dalam fasilitas pencetakan 3D dan pengelolaan melalui pembuatan bahan alternatif (alga bioplastik) dari air bekas hasil pencucian plastik, dan dengan mengajak masyarakat untuk turut ikut serta melalui program upcycling. Melalui cara ini, sampah plastik dapat diolah menjadi barang yang dapat digunakan kembali, dan hasil produk (berupa furnitur, ornamen, dan lainnya) yang sudah rusak dapat didaur ulang dan diolah kembali menjadi produk yang baru sehingga menciptakan sebuah ekonomi yang sirkuler. Selain itu, karena kesadaran masyarakat terhadap pengelolaan dan pengurangan konsumsi plastik juga menjadi bagian penting dalam mengatasi masalah ini, perancangan menerapkan pendekatan desain arsitektur sensori melalui ketujuh indera manusia (penglihatan, pendengaran, penciuman, peraba, pengecap, tulang dan otot) agar dapat menjadi bangunan yang dapat 'dirasakan' oleh penggunanya. Dengan ini, tujuan perancangan untuk membantu mengelola sampah plastik dan meningkatkan kesadaran masyarakat terhadap kondisi lingkungan sekarang ini dapat disampaikan melalui program dan pengalaman ruang yang dirasakan. Melalui penggunaan teknologi dan penerapan desain arsitektur sensori, perancangan tidak hanya menghasilkan produk olahan sampah plastik, tetapi juga menciptakan ekologi baru pada bangunan industri.
\end{abstract}

Kata kunci: arsitektur sensori; pencetakan 3D; pengalaman ruang; sampah plastik; tujuh indera

\begin{abstract}
Plastic is one of the most popular materials because of its flexiblity, low cost, and durability. However, despite being durable, a lot of plastics are only used once before ending up in landfills or the environment; piles of plastic waste can be seen floating on the sea because of their nondegradable nature. The plastic waste treatment and management facility responds to this problem in two ways, namely through processing plastic waste into raw materials used in making the filament for 3D printing, and through management, by the manufacture of alternative materials (algae bioplastic) using the wastewater obtained from washing plastics and by inviting the community to participate through upcycling. Through this, plastic waste can be converted into a usable product (such as furniture, ornaments, and others), and if said product is defected or broken, it can be recycled back and turned into raw material for another printing process, thus creating a circular economy. Furthermore, as citizens' awareness towards the proper management of plastic waste and the reduction of plastic consumption plays an important role in addressing this issue, this project uses the sensorial architecture of the seven senses (sight, hearing, smell, touch, taste, skeleton and muscle) as a design approach to make the users 'feel' the building. As a result, the purpose of this project, which is to help in managing plastic waste and to raise awareness regarding this issue, can be achieved through the programs and spatial experience. By using technology and sensorial architecture design, not only does this project generate product from plastic waste, but also creates a new ecology to an industrial building. Keywords: 3D printing; plastic waste; sensorial architecture; seven senses; spatial experience
\end{abstract}




\section{PENDAHULUAN}

\section{Latar Belakang}

Plastik merupakan salah satu bahan yang paling banyak digunakan dalam pembuatan produk karena sifatnya yang fleksibel, tahan lama, dan murah. Namun, karena tidak sedikit plastik yang hanya dapat dipakai sekali, plastik tersebut akhirnya berakir di TPA atau dibuang sembarangan sehingga menyebabkan pencemaran lingkungan, salah satunya adalah pencemaran ekosistem laut. Di Indonesia, tiap tahunnya, menghasilkan sekitar 4,84 juta ton sampah plastik, dan 44\% (2,13 juta ton) dari sampah tersebut mencemari lingkungan, daratan, dan lautan. Sejumlah studi menunjukkan bahwa dalam tahun 2025, kawasan perairan di Indonesia akan terdiri dari komposisi 3:1 untuk sampah berbanding ikan. Pada tahun 2050, jumlah sampah plastik dapat melebihi jumlah ikan di lautan jika tidak ada gerakan pengurangan sampah plastik yang signifikan.

Ekosistem laut memiliki peran yang sangat penting dalam berbagai bidang, termasuk makanan, ekonomi, detoksifikasi limbah, pariwisata, budaya, dan lainnya. Namun, pembuangan sampah plastik sembarangan pada laut, langsung maupun tidak langsung, dapat memberikan dampak yang negatif terhadap ekosistem laut. Hewan laut seperti penyu, paus, dan lainnya dapat mengira bahwa plastik tersebut adalah makanan dan mengonsumsinya. Konsumsi plastik oleh hewan air dapat menyebabkan pendarahan internal, bisul, dan penyumbatan pada saluran pencernaan (Wright et al., 2013). Selain pada binatang, sampah plastik juga mempengaruhi habitat binatang tersebut. Kehadiran mikroplastik dalam sedimen pesisir mengakibatkan perubahan sifat secara fisik dari pantai dan masalah lainnya (Carson et al., 2011).

Karena ini, berbagai upaya dan penelitian telah dilakukan untuk mengelola dan mengurangi sampah plastik yang berakhir di lingkungan, salah satunya adalah dengan menginkorporasikan sampah plastik dengan teknologi $3 D$ printing, dimana sampah plastik tidak hanya diolah kembali menjadi barang berguna (seperti furnitur, ornamen, tas, dan barang sehari-hari lainnya), tetapi juga untuk menciptakan circular economy. Selain itu, salah satu upaya dalam mengelola sampah plastik adalah dengan menggunakan bahan alternatif yang dapat mengalami proses degradasi, yaitu dengan alga bioplastik. Namun, tidak hanya melalui cara ini, tetapi perlu adanya perilaku aktif dari masyarakat dalam pengurangan konsumsi plastik agar dapat mencegah pencemaran lingkungan yang lebih parah. Karena ini, implementasi sensory architecture dalam perancangan menjadi faktor penting dalam menciptakan sebuah bangunan yang tidak hanya berfungsi untuk mengolah sampah plastik, tetapi juga untuk membantu meningkatkan kesadaran masyarakat terhadap keadaan lingkungan yang sudah tercemar oleh sampah plastik ini.

\section{Rumusan Permasalahan}

Jumlah sampah plastik yang terus bertambah di lautan sehingga memberikan dampak buruk pada ekosistem laut, lingkungan dan manusia. Tidak sedikit hewan akuatik mengonsumsi sampah plastik yang mengakibatkan permasalahan pada pencernaan, bahkan sampai kematian. Selain itu, mikroplastik yang terdapat pada hewan dapat berakhir di manusia jika mereka mengonsumsi hewan tersebut. Maka, diperlukan sebuah solusi untuk mengatasi reaksi berantai ini dan permasalahan sampah plastik yang kian meningkat.

\section{Tujuan}

Tujuan perancangan adalah untuk menciptakan arsitektur yang mengedepankan 'beyond ecology' di wilayah Papanggo dengan membantu mengolah dan mengelola sampah plastik, sekaligus mengajak masyarakat untuk turut berperan dalam pengelolaan sampah plastik.

\section{KAJIAN LITERATUR}

\section{Pengolahan dan Pengelolaan Sampah Plastik}

Menurut Swadaya (2008), konsep dari pengelolaan sampah terpadu terdiri dari beberapa tahapan, yaitu mengurangi penggunaan (reduce), menggunakannya kembali (reuse), mendaur ulang (recycle), 
mengolahnya menjadi sumber energi alternatif, dan membuang. Pengurangan sampah melalui konsep 3R (reuse, reduce, dan recycle) menurut UU nomor 18 tahun 2008 adalah: reduce, mengupayakan agar limbah yang dihasilkan seminimal mungkin; reuse, memanfaatkan kembali limbah yang dihasilkan secara langsung; dan recycle, residu atau limbah sisa yang tidak dapat dimanfaatkan secara langsung dapat diproses atau diolah, sehingga dapat dimanfaatkan sebagai bahan baku atau sumber energi.

Selain mengolah sampah plastik, dalam sebuah artikel berita BBC News yang ditulis oleh Victoria Gill, beberapa peneliti dari Universitas Manchester menyatakan beberapa langkah yang dapat dilakukan untuk mengatasi isu pencemaran sampah plastik ini, yaitu dengan mengurangi jumlah plastik yang diproduksi dan dikonsumsi, dan juga dengan mengganti plastik dengan bahan lain yang dapat di daur ulang. Salah satu profesor dari universitas tersebut bernama Jamie Woodward meresponi terhadap penggunaan plastik selama pandemi COVID-19 dengan berkata "Plastik telah membuat banyak pekerja di garis depan aman. Namun, limbah alat pelindung diri pada 10 tahun ke depan bisa mengerikan. ... Kita perlu mengubah perilaku kita secara besar-besaran." Dari pernyataan tersebut, dapat dikatakan bahwa peran masyarakat dalam pengelolaan sampah plastik sangat dibutuhkan untuk mengurangi pencemaran lingkungan. Maka dari itu, kesadaran masyarakat terhadap pencemaran lingkungan dan pengelolaan sampah plastik perlu ditingkatkan melalui pendekatan desain arsitektur sensori pada perancangan.

\section{Mendaur Ulang Sampah Plastik Menggunakan Teknologi 3D Printing}

$3 D$ printing adalah proses pembuatan objek 3 dimensi dari suatu model digital, dengan menambahkan material lapis demi lapis. Salah satu teknologi 3D printing yang banyak digunakan adalah FFF (Fused Filament Fabrication) atau yang dikenal dengan FDM (Fused Deposition Modelling). Melalui teknologi ini, filamen termoplastik dipanaskan sampai titik leleh dan diekstrusi oleh nozzle lapis demi lapis untuk membuat objek 3 dimensi, yang sudah di desain pada komputer (CAD), tersebut. Beberapa material plastik yang dapat digunakan sebagai filamen adalah ABS (acrylonitrile butadiene styrene), PLA (polylactic acid), PE (polyethylene), dan PP (polypropylene). Teknologi ini sudah banyak digunakan dalam beberapa bidang seperti arsitektur, otomotif, militer, medis, dan lainnya; potensinya untuk berkembang sangat besar dengan modifikasi-modifikasi pada teknologi tersebut untuk menciptakan mesin yang dapat membuat suatu produk dengan cepat dan dengan biaya yang lebih rendah. Meskipun begitu, terdapat kekhawatiran mengenai jumlah sampah plastik yang dihasilkan dari proses ini; produk yang salah atau yang tidak sesuai dengan ekspektasi cenderung tidak di daur ulang dan berakhir dalam tempat pembuangan sampah atau di lingkungan. Maka dari itu, terdapat beberapa penemuan yang memanfaatkan sampah plastik, termasuk hasil produk faulty dari pencetakan, sebagai bahan dasar dari filamen $3 D$ printing.

Dalam jurnal 'Reuse Plastic for 3D Printing' yang ditulis oleh Yusheng, et al, sebelum menjadi filamen untuk pencetakan 3D, terdapat beberapa proses yang harus dilalui, yaitu:

\section{Pemilahan}

Plastik dibagi menjadi beberapa jenis dan diberikan kode nomor karena perbedaan dalam karakteristik, sehingga memerlukan pendekatan yang berbeda. Maka, proses awal yang dilalui adalah pemilahan berdasarkan kode plastik tersebut. Proses pemilahan dapat dilakukan secara manual dengan tenaga kerja manusia, ataupun dengan teknologi. Beberapa teknologi pemilahan yang dapat dipakai adalah gravity separation, electrostatic separation, sensor-based sorting, magnetic density separation, dan flotation (Bonifazi dan Serranti, 2019). Sebagai contoh, salah satu mesin yang digunakan dalam industri daur ulang botol plastik adalah gravity separation menggunakan sink-floattank, dimana botol plastik (PET) dan tutup botolnya (PP) dipisahkan berdasarkan berat jenis; satu material akan mengambang, sedangkan yang satunya akan tenggelam. 


\section{Mengecilkan ukuran}

Plastik dihancurkan menjadi sekecil pellet agar mudah untuk dipanaskan dan dilelehkan secara rata, dengan ukuran maksimum $5 \mathrm{~mm}$.

\section{Pencucian dan pengeringan}

Plastik harus dibersihkan dari debu, lemak, sisa makanan, dan kontaminan lainnya. Plastik cenderung dihancurkan menjadi serpihan kecil dahulu, sebelum dimasukkan ke mesin untuk proses pembersihan; mesin pembersihan dapat melibatkan air ataupun friksi (gaya gesek) untuk membersihkan plastik dari kontaminan yang dapat mempengaruhi produk akhir. Setelah pencucian, plastik dikeringkan dan harus mencapai tingkat kelembapan tertentu agar kualitas produk akhir dapat maksimal. Mesin yang dapat dipakai untuk proses pengeringan termasuk fluid bed dryers, rotary dryers, mechanical (centrifugal) dryers, dan hot air dryers.

\section{Pembuatan filamen}

Plastik kemudian dilelehkan dan dibentuk menjadi filamen dengan diameter $1.75 \mathrm{~mm}$ atau $3 \mathrm{~mm}$, yang dapat digunakan untuk proses $3 D$ printing.

\section{Peran Alga Dalam Pengelolaan Sampah Plastik}

Alga merupakan salah satu organisme yang dapat dimanfaatkan dalam berbagai bidang, seperti kecantikan, makanan, dan dalam pengelolaan sampah plastik. Terdapat beberapa penelitian yang menunjukkan bahwa alga dapat terlibat dalam proses degradasi plastik dengan memproduksi enzim yang berinteraksi dengan makromolekul pada plastik dan menginisiasi proses degradasi dengan melemahkan ikatan kimia pada polimer plastik. Melalui proses ini, alga menghasilkan gas karbon dioksida yang akan dipakai untuk proses fotosintesis dari alga tersebut, sehingga proses ini tidak menambah pencemaran pada lingkungan.

Selain proses degradasi, alga juga dapat digunakan sebagai bahan alternatif dari plastik, yang dikenal sebagai alga bioplastik. Istilah 'bioplastik' sudah tidak asing dan terdapat beberapa bahan yang digunakan untuk membuat bioplastik, salah satunya adalah pati jagung. Namun, setelah ditemukan bahwa terdapat persaingan dengan sumber makanan, alga menjadi salah satu bahan alternatif dalam pembuatan bioplastik karena tingkat pertumbuhannya yang cepat. Untuk proses pembuatannya, alga harus melalui proses sentrifugasi, pengeringan dan hidrolisis yang menyebabkan pertumbuhan bakteri dan produksi PHB, yaitu sebuah polimer yang digunakan untuk membuat bioplastik. Maka, dari hasil penelitian tersebut, dapat dikatakan bahwa alga dapat dimanfaatkan untuk membantu mengatasi permasalahan pencemaran sampah plastik.

\section{Sensorial Architecture}

Pengalaman yang didapat dari sebuah karya arsitektur dapat menghubungkan dunia dengan tubuh penggunanya, dan menunjukkan bahwa manusia tidak terpisah dari lingkungannya. Pengalaman yang didapatkan dari sebuah ruang dalam bangunan dirasakan merata oleh semua indera yang saling berinteraksi. Dengan ini, ruang arsitektural menjadi ruang yang 'hidup' dan menjadi sesuatu yang melampaui geometri dan ukuran.

Dalam buku 'The Eyes of the Skin' dan essay 'An Architecture of the Seven Senses' yang ditulis oleh Juhani Pallasmaa, terdapat tujuh indera manusia yang terlibat dalam perancangan sebuah bangunan yang dapat berpengaruh bagi penggunanya, yaitu:

1. Penglihatan, melalui pencahayaan pada bangunan;

2. Pendengaran, yang menstrukturkan dan mengartikulasikan pengalaman dan pengertian dari sebuah ruang;

3. Penciuman, yang dapat membangkitkan memori;

4. Peraba, yang dapat menciptakan kesan yang intim dan dekat; 
5. Pengecap, dimana terdapat 'pemindahan' dari apa yang dirasakan oleh indera peraba pada indera pengecap dan dimana warna tertentu dapat membangkitkan sensasi tertentu;

6. Tulang dan otot, yaitu konstruksi bangunan yang membingkai, mengartikulasi, menghubungkan, memisahkan dan menyatukan sebuah bangunan.

\section{METODE}

\section{Metode Penelitian}

Penelitian menggunakan metode deskriptif kualitatif, dengan melihat kondisi lingkungan untuk menentukan isu dan permasalahan yang akan diangkat, yaitu mengenai sampah plastik yang mencemari ekosistem laut. Penelitian dilanjutkan dengan pengumpulan informasi mengenai isu yang diambil melalui data sekunder, yang diambil dari literatur, jurnal, e-book, dan artikel. Data yang dikumpulkan berupa sumber, jenis, dampak, dan cara pengolahan dan pengelolaan sampah plastik untuk menentukan program yang sesuai. Kelebihan dan kekurangan dari masing-masing cara pengelolaan dianalisis dan fasilitas pencetakan 3D ditentukan sebagai program utama karena dapat melibatkan peran masyarakat dalam proses desain, dan produk yang dihasilkan dapat dipakai oleh masyarakat. Produk yang dihasilkan melalui pencetakan 3D dibagi menjadi dua, yaitu skala besar (berupa street furniture) dan skala kecil (dapat berupa ornamen, mainan, wadah, dan lainnya).

Berdasarkan analisis data, ditemukan bahwa sampah domestik mempunyai kontribusi terbesar pada jumlah sampah yang terdapat di TPA; hal ini menjadi salah satu faktor yang dipertimbangkan dalam pemilihan lokasi tapak. Penentuan lokasi dan survei dilakukan secara digital melalui Google Maps dan Google Earth; sedangkan pencarian data lokasi dan tapak (berupa zonasi, luas, jumlah sampah yang dihasilkan, dan lainnya) didapatkan melalui berita, website, dan katalog yang diterbitkan oleh 'Badan Pusat Statistik Kota Jakarta Utara'.

Karena cenderung bersifat industrial, dengan lokasi tapak di area perumahan, perancangan perlu beradaptasi dengan sekitarnya agar tidak mengganggu warga perumahan. Untuk melakukan ini, perancangan mengambil pendekatan desain sensorial architecture yang berfokus pada penggunaan indera manusia dalam merasakan suatu ruang untuk menciptakan sebuah bangunan yang terhubung dengan lingkungannya dan menciptakan suasana baru pada bangunan industri. Pendekatan desain sensorial architecture yang diaplikasikan pada bangunan didasarkan atas teori Juhani Pallasmaa pada buku 'The Eyes of the Skin' dan essay 'An Architecture of the Seven Senses' yang terdapat pada salah satu bagian buku 'Questions of Perception: Phenomenology of Architecture'. Setelah menganalisis kedua sumber tersebut, dapat disimpulkan bahwa penerapan arsitektur sensori pada bangunan melibatkan tujuh indera manusia, yaitu: penglihatan, pendengaran, pengecap, penciuman, peraba, otot dan tulang; yang diterapkan melalui penggunaan material, pencahayaan, pengudaraan, desain lansekap, dan lainnya untuk menciptakan sebuah ruang yang dapat 'dirasakan' oleh penggunanya.

\section{DISKUSI DAN HASIL}

\section{Pemilihan Lokasi}

Berdasarkan permasalahan dan tujuan perancangan, terdapat beberapa kriteria lokasi tapak yang ditetapkan, yaitu: memiliki permasalahan sampah, dekat dengan badan air agar kontekstual dengan permasalahan yang diambil, dekat dengan daerah permukiman karena masyarakat setempat mempunyai peran yang sangat penting dalam pengelolaan sampah, dekat dengan area publik dimana salah satu produk hasil pencetakan 3D (street furniture) dapat diaplikasikan langsung tanpa biaya transportasi yang tinggi, dan juga terdapat akses untuk truk sampah. Berdasarkan kriteria tersebut, kota Jakarta dipilih karena merupakan kota dengan jumlah penduduk terbanyak di Indonesia, dan Jakarta Utara dipilih karena letaknya yang dekat dengan badan air.

Terdapat dua alternatif lokasi yang dipilih, yaitu di Jalan Sakapura Timur II yang berlokasi di Cilincing, dan Jalan Danau Bisma di Papanggo. Setelah melakukan analisis, yang terdapat pada Tabel 1, tapak 
dipilih di Papanggo karena memenuhi kriteria dan fasilitas yang terdapat di sekitar tapak dapat mendukung program dan tujuan dalam perancangan.

Tabel 1. Perbandingan Lokasi Tapak

\begin{tabular}{|c|c|c|c|}
\hline \multirow{3}{*}{ Kriteria } & Tapak 1 & Tapak 2 & \multirow{3}{*}{ Keterangan } \\
\hline & & & \\
\hline & $\begin{array}{c}\text { JI. Sakapura Timur II, } \\
\text { Cilincing }\end{array}$ & Jl. Danau Bisma, Papanggo & \\
\hline $\begin{array}{l}\text { Isu } \\
\text { Kontekstual } \\
\text { Sampah }\end{array}$ & $\begin{array}{l}\text { Terdapat tumpukan } \\
\text { sampah yang dibiarkan } \\
\text { begitu saja pada lahan } \\
\text { kosong tersebut }\end{array}$ & $\begin{array}{l}\text { Terdapat TPS Waduk Cincin } \\
\text { tetapi sampah tidak } \\
\text { dikelola; sampah dibuang } \\
\text { di lahan yang disediakan } \\
\text { dan dibakar }\end{array}$ & $\begin{array}{l}\text { Kedua tapak memiliki } \\
\text { masalah pencemaran } \\
\text { lingkungan akibat sampah } \\
\text { yang tidak dikelola dengan } \\
\text { baik }\end{array}$ \\
\hline Fasilitas & $\begin{array}{l}\text { Terdapat industri, } \\
\text { permukiman, dan toko } \\
\text { di sekitar tapak }\end{array}$ & $\begin{array}{l}\text { Terdapat industri, } \\
\text { permukiman, dan Danau } \\
\text { Cincin sebagai ruang } \\
\text { publik dan area rekreasi }\end{array}$ & $\begin{array}{l}\text { Kedua tapak memiliki fasilitas } \\
\text { yang dapat mendukung } \\
\text { program (industri dan } \\
\text { permukiman); tetapi tapak } \\
\text { kedua memiliki ruang publik } \\
\text { yang bisa digunakan untuk } \\
\text { showcase produk furnitur } \\
\text { hasil pencetakan 3D }\end{array}$ \\
\hline Akses & $\begin{array}{l}\text { Akses ke tapak hanya } \\
\text { melalui jalan utama } \\
\text { Jalan Sakapura Timur II } \\
\text { dengan luas } 8 \text { meter }\end{array}$ & $\begin{array}{l}\text { Terdapat } 3 \text { akses ke dalam } \\
\text { tapak dengan luas: Jl. } \\
\text { Danau Bisma (utama) - } 15 \\
\text { m, Jl. Bisma Utara - } 10 \text { m, } \\
\text { Jl. Papanggo IV - } 6 \text { m }\end{array}$ & $\begin{array}{l}\text { Tapak kedua memiliki akses } \\
\text { yang lebih memadai karena } \\
\text { mempunyai jalur kendaraan } \\
\text { yang lebih luas dan dapat } \\
\text { diakses dari } 3 \text { jalur untuk } \\
\text { membedakan akses } \\
\text { kendaraan publik dan servis, } \\
\text { sehingga kemacetan dapat } \\
\text { dihindari }\end{array}$ \\
\hline
\end{tabular}

Sumber: Google Maps Satellite View (Gambar); Analisis Pribadi, 2021

\section{Lokasi dan Data Tapak}

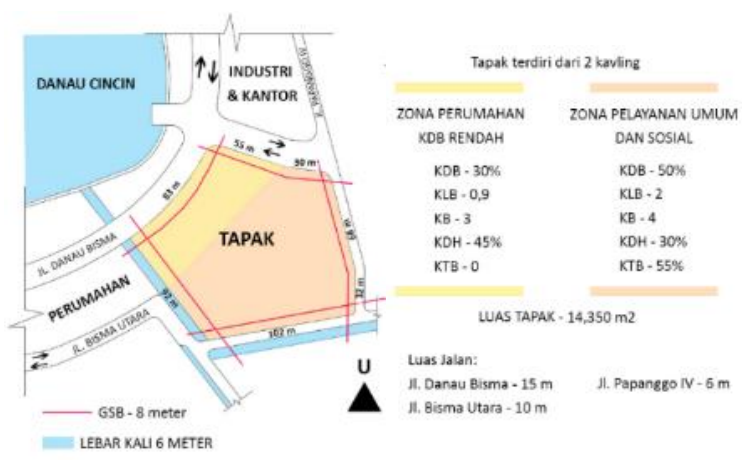

Gambar 1. Data Tapak

Sumber: Penulis, 2021

Tapak berlokasi di Jalan Danau Bisma, Papanggo, Kecamatan Tanjung Priok, Jakarta Utara, yang 
berseberangan dengan Danau Cincin. Tapak mengambil dua kavling dengan luas sebesar 14,530 m2. Selain danau, terdapat industri, perumahan, dan tempat pembuangan sampah di sekitar tapak.

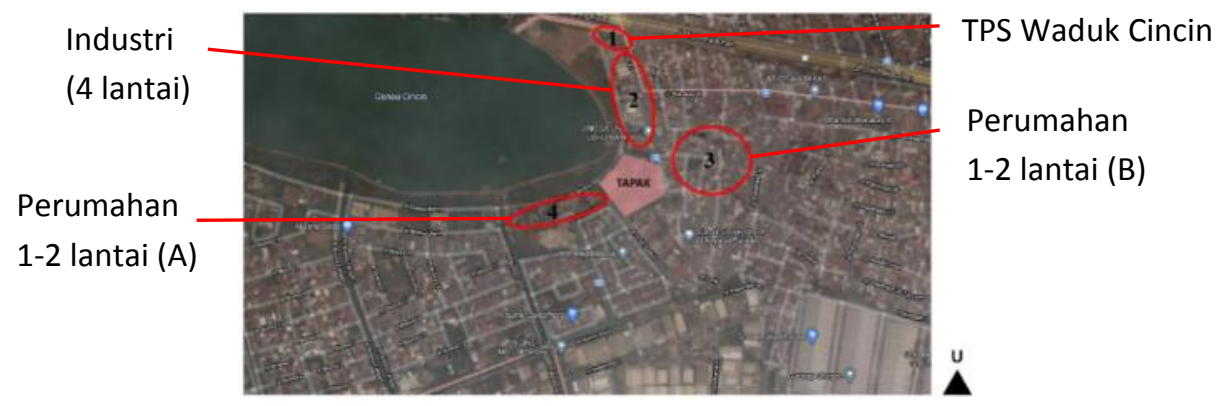

Gambar 2. Fasilitas sekitar Tapak Sumber: Google Maps Satellite View

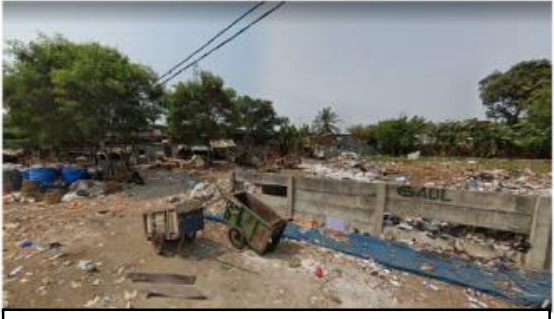

TPS Waduk Cincin

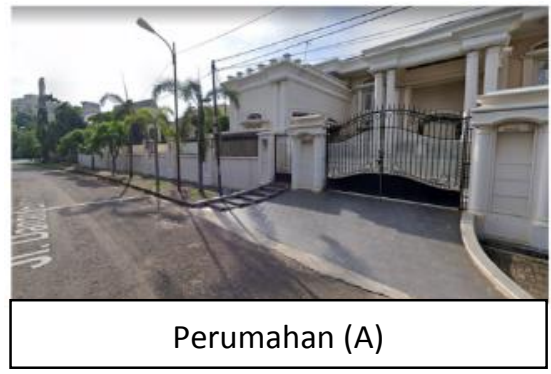

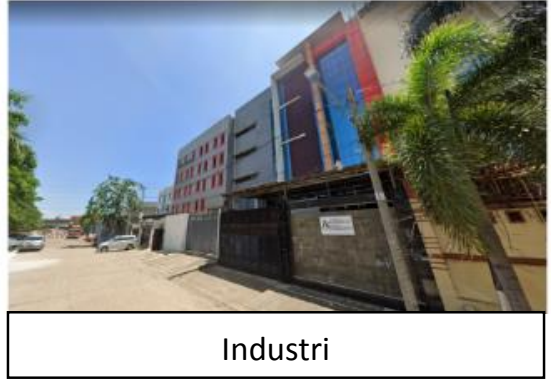

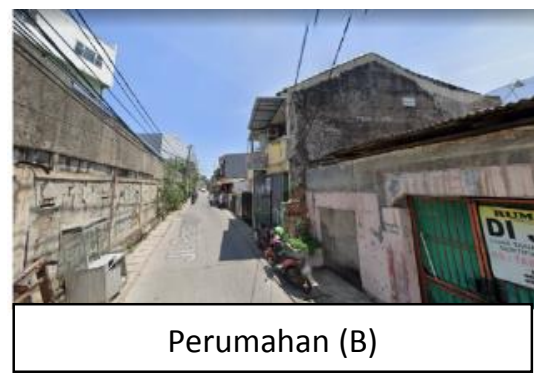

Gambar 3. Kondisi Sekitar Tapak

Sumber: Google Maps Street View

\section{Produk Hasil Perancangan}

Program utama yang terdapat pada perancangan meliputi pencetakan 3D, sebagai fasilitas pengolahan, dan algae cultivation centre sebagai salah satu fasilitas pengelolaan. Pencetakan 3D dibagi menjadi dua, yaitu skala besar dan kecil; skala besar memproduksi furnitur dan ornamen yang dapat digunakan pada bangunan, sedangkan skala kecil memproduksi mainan, alat makan, dan lainnya yang dapat digunakan sehari-hari. Dengan cara ini, konsep circular economy dapat dicapai; sampah plastik diolah menjadi barang yang dapat digunakan kembali, produk yang rusak dapat melalui proses dari awal (shredding, pencucian, pengeringan) untuk menjadi bahan dasar pencetakan 3D.

Karena melibatkan sampah plastik, pencucian menjadi salah satu proses penting yang harus dilalui sebelum proses pencetakan. Untuk mengolah air bekas dari pencucian tersebut, perancangan menerapkan konsep self-recycling, dimana air tersebut akan dialirkan ke algae raceway pond, yang tedapat pada algae cultivation centre, untuk difilter menjadi air bersih yang dapat digunakan kembali. Penggunaan alga sebagai wastewater treatment sudah banyak digunakan, dan terdapat sebuah penelitian yang menunjukkan bahwa alga juga dapat membantu proses degradasi plastik. Oleh karena itu, penggunaan alga sebagai pengolahan air bekas tidak hanya untuk memproduksi air bersih, tetapi juga agar residu plastik yang tersisa tidak mencemari lingkungan sekitarnya. 
Selain untuk pengolahan air bekas, alga mempunyai banyak manfaat lainnya yang dapat digunakan oleh manusia, salah satunya adalah sebagai bahan alternatif plastik, yaitu alga bioplastik, yang dapat menjadi salah satu solusi dalam penanganan sampah plastik. Melalui proses sentrifugasi, air bersih dan alga yang dihasilkan dari proses pengolahan akan dipisah, air bersih akan dialirkan ke ruang penampungan air, sedangkan alga akan melalui proses riset dan pengolahan untuk membuat alga bioplastik, bahan alternatif plastik yang dapat mengalami proses degradasi.

\section{Penerapan Sensorial Architecture pada Perancangan}

Lokasi tapak berada di antara industri dan perumahan yang memiliki karakteristik dan keperluan ruang yang berbeda; industri cenderung bersifat keras dan mengeluarkan bising dari mesin yang dipakai, sedangkan rumah membutuhkan kehangatan dan ketenangan. Namun, hubungan antara keduanya menjadi tujuan dari proyek, yaitu untuk merancang sebuah bangunan yang tidak hanya membantu mengolah sampah plastik, tetapi juga agar masyarakat dapat ikut serta dalam pengelolaan. Perancangan tidak hanya bersifat industrial yang terkesan kasar, tetapi untuk menginkorporasikan sifat yang lembut dengan adanya unsur rekreasi agar masyarakat setempat tidak merasa terganggu dengan adanya bangunan tersebut. Melalui pendekatan desain sensorial architecture, lingkungan, masyarakat, dan program dapat dihubungkan menjadi satu kesatuan; dimana pengguna dapat 'merasakan' bangunan melalui ruang yang dilewati, mulai dari lansekap hingga ke interior bangunan, dan merasakan suasana yang berbeda dalam sebuah bangunan industrial.

Pada awal perancangan, tapak dibagi menjadi tiga zona, yaitu: area pengolahan (industri pencetakan 3D menggunakan sampah plastik), pengelolaan (rekreasi), dan servis dan karyawan. Area rekreasi ditempatkan di bagian depan tapak, yang berseberangan dengan Danau Cincin, sedangkan area industri ditempatkan di bagian belakang, dan kedua zona tersebut dihubungkan dengan area karyawan dan servis yang ditempatkan di bagian tengah. Area tersebut dihubungkan dengan ramp pada bagian outdoor sebagai sirkulasi utama; ramp ditempatkan di bagian luar agar pengguna bangunan tetap dapat berinteraksi dan tidak terlepas dari lingkungannya.

Setelah menganalisis buku dan essay yang ditulis oleh Juhani Pallasmaa, ketujuh indera diaplikasikan pada perancangan melalui beberapa cara, yaitu:

\section{Indera Penglihatan}

Lokasi tapak yang berdekatan dengan Danau Cincin menawarkan pemandangan danau yang dapat dinikmati oleh pengguna bangunan; bangunan diorientasikan menghadap danau sehingga pengguna dapat menikmati view danau sembari menikmati suasana matahari terbenam. Selain view, indera ini juga diterapkan pada ruangan dalam dengan melibatkan pencahayaan alami.

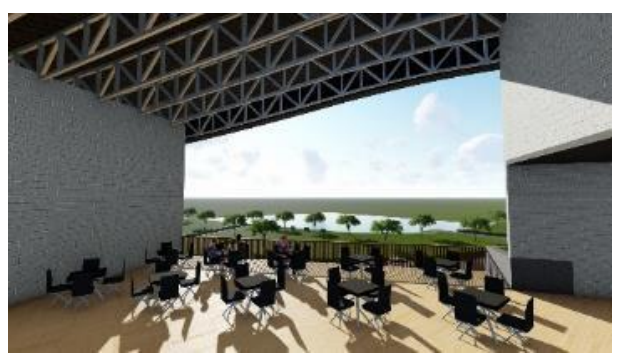

Gambar 4. View Dari Dalam Bangunan Sumber: Penulis, 2021

Pengolahan air bekas cuci plastik melibatkan peran alga dalam sebuah raceway pond untuk memfilter air bekas menjadi air yang dapat digunakan kembali untuk proses pencucian selanjutnya. Selain berperan sebagai salah satu program untuk pembuatan bioplastik, kolam tersebut dapat digunakan sebagai salah satu cara untuk pengaplikasian arsitektur sensori. Karena terdapat semi-basement 
dibawah algae cultivation centre (letak raceway pond), sebagian dari kolam dapat menggunakan kaca sebagai base dari kolam tersebut. Dengan adanya kaca, pengguna bangunan yang berada di semibasement dapat melihat secara langsung flow dari air dan alga yang terlibat dalam proses filter air. Selain itu, warna airnya yang hijau (akibat alga) dapat memberikan kesan dan suasana tersendiri bagi pengguna bangunan yang sedang berada di semi-basement.
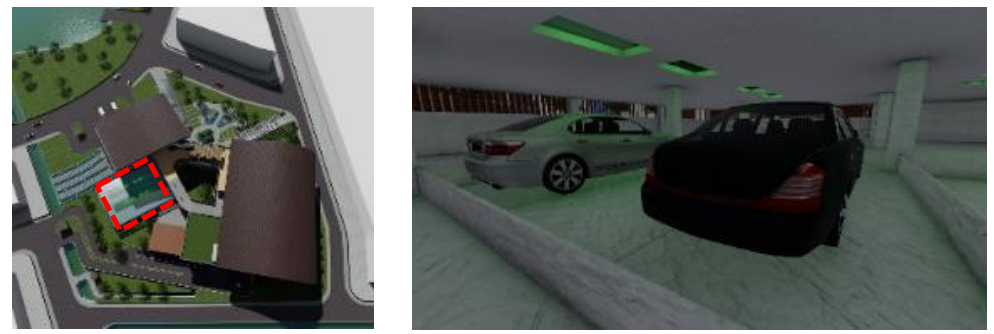

Gambar 5. Algae Pond Glass-bottom Pool Sumber: Penulis, 2021

Indera penglihatan juga distimulasi oleh adanya algae tube yang terhubung dari area riset di lantai dasar ke ruang workshop alga bioplastik pada lantai 2. Bukaan berhadapan dengan algae tube sehingga cahaya alami dapat menembus dan menciptakan kesan alami dari warna hijau yang dihasilkan, menciptakan suasana yang natural dan sejuk saat pengunjung / pegawai membuat alga bioplastik.

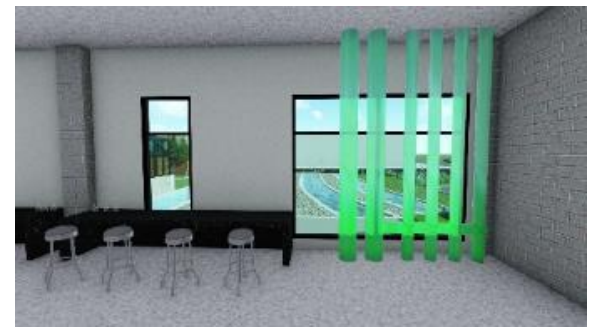

Gambar 6. Algae Tube pada Ruang Riset

Sumber: Penulis, 2021

Selain itu, terdapat juga permainan bayangan dan cahaya pada instalasi, yang merupakan salah satu produk dari pencetakan 3D sampah plastik, yang terdapat di akses pedestrian untuk mengundang pengunjung untuk datang.
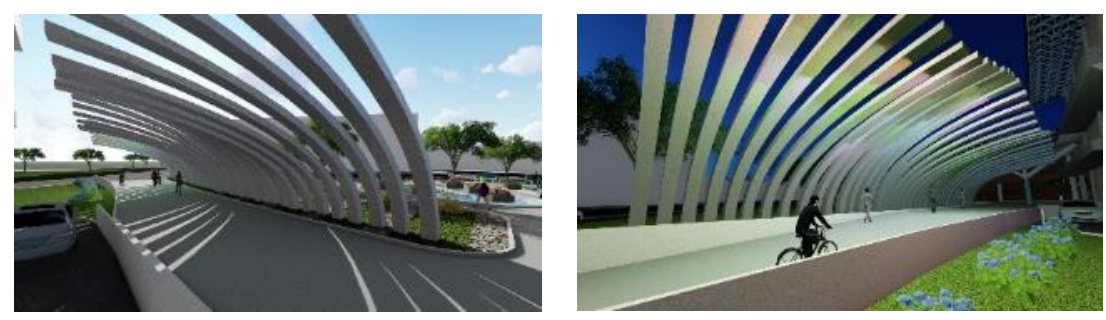

Gambar 7. Instalasi pada Akses Pedestrian (Siang dan Malam)

Sumber: Penulis, 2021

\section{Indera Peraba}

Sebagai salah satu program bangunan, pembuatan bioplastik menggunakan alga juga melibatkan indera peraba dalam memegang alga tersebut. Tidak hanya pekerja, pengunjung juga dapat ikut serta dalam pengolahan alga menjadi bioplastik; untuk melakukan ini, pengguna bangunan dapat terlebih dahulu merasakan tekstur alga yang lembut sebelum mengolahnya menjadi suatu produk yang padat. 
Perancangan melibatkan peran masyarakat dalam sebuah industri; selain pengolahan alga menjadi bahan alternatif plastik, terdapat juga program pendukung, yaitu upcycling centre, yang terdiri dari gardening dan pembuatan suatu seni / produk yang dapat digunakan kembali menggunakan plastik bekas. Dalam kedua program ini, indera peraba turut berperan dalam merasakan tekstur tanah dan tanaman dalam program gardening, dan juga dalam pembuatan produk dari plastik bekas.

\section{Indera Pendengaran}

Perancangan bersifat industrial dan rekreasional; untuk mencegah kebisingan dari mesin, bangunan industri menggunakan material cork, yaitu lapisan luar pohon, yang dapat berfungsi sebagai buffer suara dan panas. Ketebalan cork yang digunakan pada bagian dalam dan luar berbeda; karena cork berfungsi untuk menyerap suara dari mesin, pada bagian dalam menggunakan panel yang lebih tebal. Cork panel yang digunakan mempunyai dimensi $1000 \mathrm{~mm} \times 500 \mathrm{~mm}$, dengan ketebalan $1200 \mathrm{~mm}$ pada bagian dalam dan $500 \mathrm{~mm}$ pada fasad bangunan.

Untuk area rekreasi dan yang bersifat publik, bangunan menggunakan material dinding bata dengan finishing batu alam. Berbeda dengan area industri, penggunaan batu alam dapat memantulkan suara dari pengguna bangunan sehingga menciptakan suasana yang berbeda pada sebuah bangunan pengolahan sampah plastik. Dengan perbedaan material ini, suara mesin dapat diminimalisir, sedangkan suara orang tertawa dan mengobrol dapat terdengar di sekeliling tapak, sehingga menciptakan kesan kebersamaan.

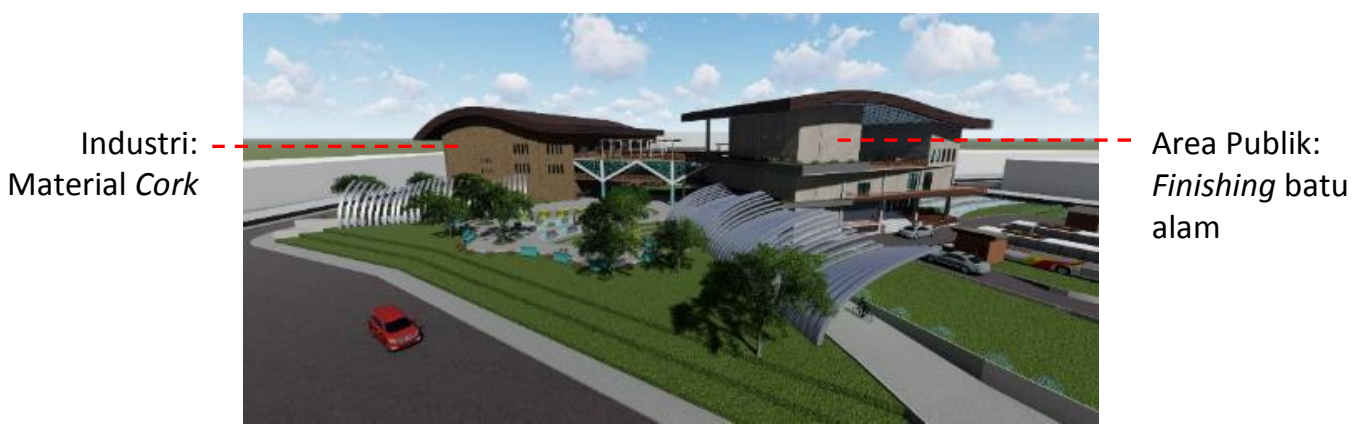

Gambar 8. Perspektif Eksterior

Sumber: Penulis, 2021

\section{Otot dan Tulang}

Konstruksi dan struktur berperan sebagai tulang bangunan, sedangkan otot menciptakan volum pada tulang tersebut. Dalam perancangan ini, otot diterapkan pada struktur bangunan berupa instalasi yang tidak hanya berfungsi sebagai ornamen, tetapi juga untuk menciptakan pengalaman spasial yang berbeda. Instalasi yang ditampilkan dapat menggunakan plastik bekas atau hasil dari pencetakan 3D sampah plastik. Melalui ini, diharapkan dapat meningkatkan kesadaran masyarakat terhadap bahaya pencemaran sampah plastik di lingkungan, dan bahwa peran mereka sangat penting dalam mengatasi masalah ini.

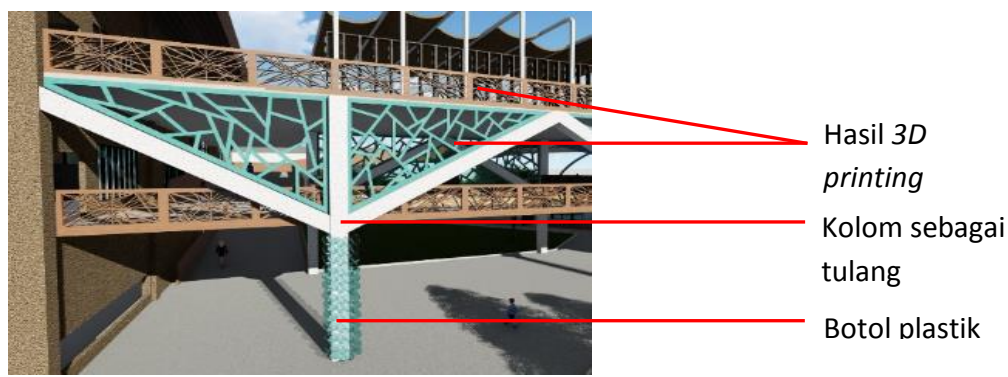

Gambar 9. Ornamen pada Struktur sebagai Otot Bangunan Sumber: Penulis, 2021 


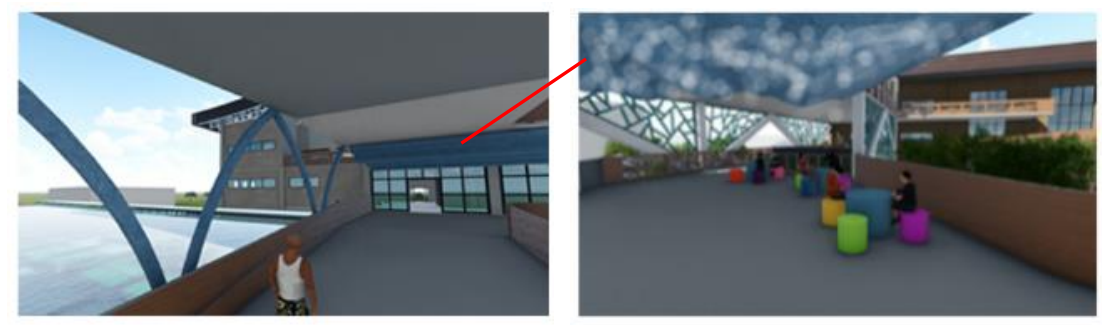

Gambar 10. Instalasi Botol Plastik

Sumber: Penulis, 2021

Tulang direpresentasikan melalui struktur yang membingkai sebuah bangunan. Pada perancangan ini, tulang dapat dilihat melalui kolom dan struktur atap yang di expose.

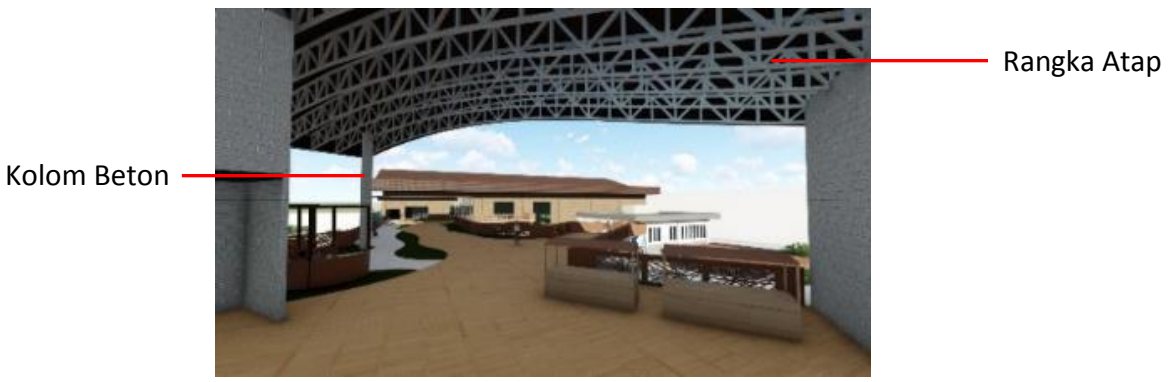

Gambar 11. Tulang Bangunan

Sumber: Penulis, 2021

5. Indera Penciuman

Karena masyarakat masih belum terbiasa untuk memilah sampah, sampah plastik yang dibawa oleh truk tetap dapat mengeluarkan bau yang tidak sedap, walaupun tidak dengan intensitas yang sama dengan sampah pada umumnya. Maka, untuk mencegah ketidaknyamanan pengunjung, masalah bau diresponi dengan penempatan area industri di bagian belakang tapak, menurunkan peil lantai setinggi 1 meter dari area publik, dan dengan ditanami tanaman sekeliling bangunan sebagai buffer bau.

Meski fasilitas pengolahan sampah cenderung identik dengan bau yang tidak sedap, namun, dengan adanya lansekap, indera penciuman dapat distimulasi pada arah yang berbeda. Perancangan mempunyai lansekap yang mengambil $39 \%$ dari luas tapak, yang terdiri dari penggabungan unsur biru dan hijau. Dari ruang terbuka ini, pengunjung dapat mencium bau tanah yang dapat membangkitkan memori masa kecil saat mereka bermain bersama teman / keluarga di taman. Indera penciuman tidak hanya terlibat saat pengunjung berada di ruang luar, tetapi juga saat berada di dalam bangunan. Karena bangunan bersifat terbuka dan dihubungkan melalui ramp outdoor, udara dapat bersirkulasi ke dalam / luar tapak dengan mudah. Maka, bau dari danau dan ruang terbuka pada tapak juga dapat dirasakan oleh pengunjung yang sedang berada di lantai 2 atau 3. Dengan ini, pengunjung tetap dapat mencium bau yang segar dari air dan tanaman yang terdapat di tapak.
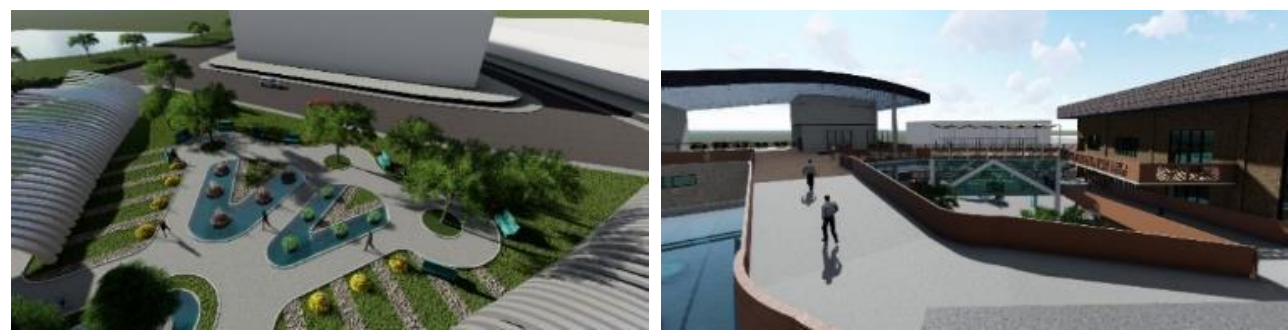

Gambar 12. Indera Penciuman Melalui Lansekap dan Area Terbuka

Sumber: Penulis, 2021 


\section{Indera Pengecap}

Walaupun tidak bersifat dominan dan tidak dirasakan secara langsung, indera pengecap dapat distimulasi melalui mata (indera penglihatan) dan apa yang dirasakan oleh tangan (indera peraba). Melalui warna yang dilihat oleh mata, dapat memberikan efek psikologis yang dapat dirasakan. Dalam perancangan ini, perbedaan warna dapat dilihat antara area industri dan area publik melalui material yang digunakan; area industri menggunakan material cork yang berwarna cokelat sedangkan area publik menggunakan finishing batu alam yang berwarna putih abu-abu. Dengan menggunakan warna cokelat yang gelap, area industri menciptakan kesan yang berat dengan adanya mesin-mesin pengolahan sampah plastik, sedangkan untuk area publik menggunakan warna yang cerah untuk menciptakan kesan yang bersih dan lebih tenang.
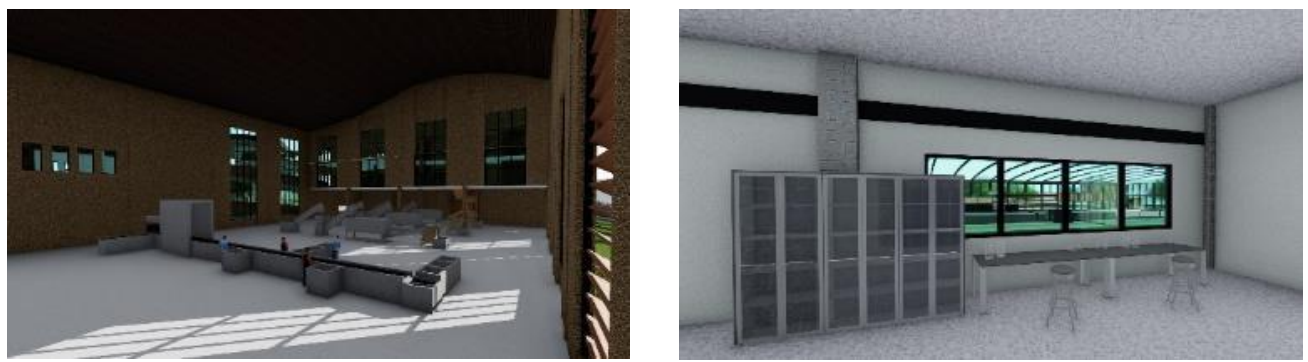

Gambar 13. Industri (kiri) dan Ruang Riset Alga (kanan)

Sumber: Penulis, 2021

Selain warna, indera pengecap juga dapat dipengaruhi oleh apa yang dipegang oleh tangan. Salah satu program yang melibatkan indera peraba adalah pembuatan alga bioplastik, dimana tekstur alga yang lembut tersebut dapat menstimulasi rasa tertentu pada lidah.

\section{KESIMPULAN DAN SARAN}

\section{Kesimpulan}

Melalui fasilitas pengolahan dan pengelolaan, sampah plastik dapat diolah melalui fasilitas pencetakan 3D untuk menghasilkan produk berupa furnitur, ornamen, dan mainan yang dapat digunakan oleh masyarakat; selain itu, pengelolaan sampah plastik juga dilakukan melalui pembuatan bahan alternatif, berupa alga bioplastik, dan program upcycling. Melalui perancangan ini, sampah plastik yang masuk ke TPA dan lingkungan dapat dikurangi, sekaligus menginisiasi konsep circular economy melalui proses daur ulang sampah plastik dan produk hasil pencetakan 3D; dampak buruk ke lingkungan pun dapat diminimalisir karena air bekas cuci plastik dapat dimanfaatkan kembali untuk pembuatan bioplastik.

Selain itu, perancangan melibatkan pendekatan desain sensorial architecture pada bangunan yang cenderung bersifat industrial untuk menciptakan suatu ekologi baru, dimana sebuah industri tidak dipandang sebagai sebuah fungsi yang berdiri sendiri yang terkesan 'kasar', namun sebagai suatu fungsi yang juga berinteraksi dengan lingkungan dan penggunanya. Hal ini dilakukan melalui penggabungan fungsi antara industrial dan rekreasional, material yang dipakai, dan juga pengolahan ruang dari luar ke dalam. Selain mengubah persepsi masyarakat mengenai industri, pendekatan desain ini juga membantu meningkatkan kesadaran masyarakat mengenai kondisi pencemaran lingkungan akibat sampah plastik melalui ruang dan instalasi yang dilalui. Dengan ini, perancangan tidak hanya membantu mengurangi sampah plastik dengan mengolahnya menjadi produk fisik, tetapi juga memberikan pengalaman ruang dan suasana yang berbeda pada penggunanya.

\section{Saran}

Penerapan desain sensorial architecture dapat dikembangkan lagi melalui analisis material dan ruang yang lebih mendalam. Selain itu, karena teknologi pencetakan 3D berpotensi besar untuk terus berkembang dan telah digunakan untuk membuat rumah di beberapa tempat, pencetakan dengan 
sampah plastik dapat dipelajari lagi agar tidak hanya digunakan untuk furnitur dan keperluan seharihari, tetapi juga untuk 'mencetak' sebuah bangunan. Dengan ini, sampah plastik tidak lagi dilihat sebagai sesuatu yang harus dibuang, tetapi sebagai sesuatu yang berharga.

\section{REFERENSI}

Bonifazi, Giuseppe dan Silvia Serranti. (2019). Techniques for Separation of Plastic Wastes. Diakses 3 Juli 2021 dari https://www.sciencedirect.com/science/article/pii/B9780081026762000025.

Carson, Henry S., S. L. Colbert, M. J. Kaylor dan K. J. McDermid. (2011). Small Plastic Debris Changes Water Movement and Heat Transfer Through Beach Sediments. Marine Pollution Bulletin, 62(8), 1708-1713.

Chia, Wen Yi, D. Y. Y. Tang, K. S. Khoo, A. N. K. Lup, dan K. W. Chew. (2020). Nature's Fight Against Plastic Pollution: Algae For Plastic Biodegradation and Bioplastics Production. Environmental Science and Ecotechnology, Volume 4.

Cordova, M. Reza. (2017). Pencemaran Plastik di Laut. Oseana, 42(3), 21-30.

Feng, Y., A. Kennedy, E. Miyajima, T. Ng, dan S. Seo. (2020). Reuse Plastic for 3D Printing. (Major Qualifying Project Report, Worcester Polytechnic Institute).

Gill, V. (2020). 'Mengerikan', Sampah Plastik Sebanyak 1,3 Miliar Ton Akan Mencemari Lingkungan pada 2040. Diakses 31 Maret 2021 dari https://www.bbc.com/indonesia/majalah- 53522290.

Kumar, R.V., G. R. Kanna, dan S. Elumalai. (2017). Biodegradation of Polyethylene by Green Photosynthetic Microalgae. Journal of Bioremediation \& Biodegradation, 8:381.

Lehrer, J dan Marietta S. (2017). The Development of a Sustainable Technology for 3D Printing Using Recycled Materials. Pennsylvania: Fall 2017 Mid-Atlantic ASEE Conference.

Pallasmaa, J. (2005). The Eyes of the Skin. (Preface oleh Steven Holl) [Electronic Version]. Sussex: John Wiley \& Sons Ltd.

Pallasmaa, J, Holl, S dan Perez-Gomez, A. (1994). Questions of Perception: Phenomenology of Architecture [Electronic Version]. Tokyo: a+u Publishing Co., Ltd. Hal 29-37.

Pratomo, H B. (2018). 5 Fakta Mencengangkan di Balik Sampah Plastik Milik Indonesia. Diakses 21 Februari 2021 dari https://www.merdeka.com/uang/5-fakta-mencengangkan-di-baliksampah-plastik-milik-indonesia.html?page $=6$.

Swadaya. (2008). Penanganan dan Pengolahan Sampah. Jakarta: Penebar Swadaya.

Tiara, D R, Iswanto, dan A. Suyanto. (2018). Pengaruh Model Tempat Sampah Pencacah Plastik Terhadap Penurunan Volume dan Peningkatan Nilai Ekonomi Sampah. (Skripsi Thesis, Poltekkes Kemenkes Yogyakarta). Diakses 21 Maret 2021 dari http://eprints.poltekkesjogja.ac.id/1083/2/4\%20BAB\%20II.pdf.

Wright, S.L., R.C. Thompson dan T. S. Galloway. (2013). The Physical Impact of Microplastics on Marine Organisms: A Review. Environmental Pollution, 178, 483-492. 
